\title{
SURVEY OF CHESTNUT NUT-ROT IN NEW ZEALAND
}

\author{
K.D.R. WADIA ${ }^{1}$, D. KLINAC ${ }^{2}$ and D.L. McNEIL ${ }^{1}$ \\ ${ }^{1}$ Soil, Plant and Ecological Sciences Division, PO Box 84, \\ Lincoln University, Canterbury \\ ${ }^{2}$ HortResearch, Ruakura Research Centre, Private Bag 3123, Hamilton
}

\begin{abstract}
Nut-rot during storage is a serious problem in New Zealand chestnuts and is causing severe economic loss to the industry. During the 1998 season, nut samples of 31 varieties from grower properties and research orchards in the North and South Island were assessed for fungal infection and rotting. The fungus Phomopsis castanea was found to be associated with both rotten and healthy nuts in all the North Island samples, although there was a large variation in incidence between varieties and locations. Samples from Rotorua, Bulls and Taupo had lower disease incidence while samples from South Auckland, Waikato, Whangarei, Bay of Plenty and Tauranga had the highest disease incidence. $P$. castanea was not found in growers' samples from the South Island, although it was associated with all six varieties from Lincoln University Orchard. Other fungi isolated from rotten nuts were Botrytis cinerea and species belonging to Penicillium, Fusarium and Pestalotia.
\end{abstract}

Keywords: Castanea sativa, Phomopsis castanea.

\section{INTRODUCTION}

Chestnuts (Castanea spp.) have the potential to be a high health, high value export crop for New Zealand growers but nut-rot during storage is an important problem causing considerable economic loss to the industry (Klinac and Forbes 1998). Phomopsis castanea has been implicated as a major cause of nut rots, but it is not the only possible causative organism. P. castanea was first isolated from New Zealand chestnuts in 1993 (D. Klinac pers. comm.). It causes severe economic losses in the Australian industry, but does not appear to be as severe in the European producing areas (Washington et al. 1997). This study attempted to identify the causal organisms, assess the extent of losses and spread of the disease in New Zealand. Previous studies have suggested a lower incidence in the South Island relative to the North Island (McNeil 1996).

\section{Nut sampling}

\section{METHODS}

Random samples of some important cultivars from the main growing regions across the country were collected between April-June 1998 as part of the AgMardt project No. 9817, "New Zealand Chestnut Nationwide Quality Survey". Nut samples were obtained from 16 growers from the North Island (South Auckland, North Auckland, Waikato, Whangarei, Bay of Plenty, Tauranga, Levin, Rotorua, Taumaranui, Bulls, Gisborne, Hawkes Bay and Taupo) and two growers from the South Island (Canterbury and Queenstown). A range of chestnut cultivars were also examined from the chestnut cultivar collections at Waikato Research Orchard (Rukuhia, $10 \mathrm{~km} \mathrm{SE}$ of Hamilton) and Lincoln University Orchard (Canterbury). Together, these comprised 63 samples covering most of the chestnut cultivars currently available in New Zealand. Isolations and nut-rot assessment

All samples were cool-stored $\left(0-5^{\circ} \mathrm{C}\right)$ for $12-16$ weeks before assessment. Fifteentwenty apparently healthy nuts from each sample were selected and were cut open in the laminar flow after surface sterilisation. The extent of rotting, rotting symptoms, embryo number and extent of pellicle intrusions were noted. Kernel pieces (about $1 \mathrm{~mm}^{3}$ ) 
immediately beneath the pellicle layer of the stylar and hilum ends of each nut (rotted and healthy) were plated onto Petri plates containing potato dextrose agar (PDA, 39g/ litre) and incubated at $20^{\circ} \mathrm{C}$. After 4 days of incubation, the fungal colonies developing from the tissue were microscopically identified using standard manuals.

\section{Grower orchards}

\section{RESULTS}

$P$. castanea was found to be associated with both rotten and healthy nuts for all the 32 samples tested from the North Island, although there was a large variation between cultivars as well as locations (Table 1).

TABLE 1: Variation in Nut-rot in samples from grower orchards in the North and South Islands.

\begin{tabular}{cccccc}
\hline Location & Cultivar & Rotted- & Predominant & \multicolumn{3}{c}{$\%$ P. castanea isolation } \\
& nuts & fungus & Stylar & Hilum & Total \\
& $(\%)$ & isolated & end & end & nuts
\end{tabular}

\section{North Island}

South Auckland 11015

South Auckland $21005 \quad 53$

$\begin{array}{lll} & 1002 & 53 \\ \text { Waikato } & \mathrm{N} 4 & 86\end{array}$

$\begin{array}{lll} & \text { K39 } & \\ \text { Whangarei } & 1015 & 80\end{array}$

Bay of Plenty $1015 \quad 80$

$\begin{array}{lll}\text { Tauranga } & 1002 & 73 \\ & 1002 & 53\end{array}$

73

53

86

0

$1007 \quad 40$

$1015 \quad 40$

Levin

1005

$1005 \quad 67$

North Auckland 1005

Rotorua $1 \quad 1005$

1002

1015

1007

Rotorua $2 \quad 1015$

Taumaranui $1 \quad 1015$

Taumaranui $2 \quad 1015$

Bulls

1015

1002

1015

Tolaga $9 \quad 13$

$1018 \quad 6$

Gisborne $\quad 1718 \quad 13$

Hawkes Bay Puketapu 6

\begin{tabular}{lrrrrrr} 
Taupo & 1005 & 0 & - & 20 & 20 & 33 \\
& 1015 & 0 & - & 13 & 67 & 80 \\
South Island & & & & & & \\
Canterbury & 1005 & 0 & - & 0 & 0 & 0 \\
& 1015 & 0 & - & 0 & 0 & 0 \\
Queenstown & 1015 & 13 & 3 & 0 & 0 & 0 \\
& 1002 & 0 & - & 0 & 0 & 0 \\
\hline
\end{tabular}

${ }^{1} 1=$ Phomopsis castanea, $2=$ Penicillium $\mathrm{sp} ., 3=$ Fusarium $\mathrm{sp}$. 
For example, 73-93\% nuts of cultivar 1015 sourced from South Auckland were rotten, whereas no rotting was observed in the same cultivar from Taupo, even though $P$. castanea was isolated from $80 \%$ of these nuts. Cultivars 1007 (Rotorua), Puketapu (Hawkes Bay) and 1018 (Bulls) had less than 10\% rotten nuts, even thoughP. castanea was isolated from about 25,40 and $60 \%$ of nuts, respectively, from these samples. Cultivar K39 is known to store well and showed no rotting and only $20 \% P$. castanea isolation compared to N4 from the same Waikato orchard which is known to store poorly and had $85 \%$ rotten nuts and $93 \%$ P. castanea isolation. P. castanea was not isolated from grower samples from the South Island; however Fusarium sp., caused some rotting in cultivar 1015 from Queenstown.

\section{Research orchards}

From the Waikato Research Orchard, 20 out of the 21 cultivars tested had rotten nuts (the only exception being 1007) and the fungus $P$. castanea was by far the most common species associated with this rotting (Table 2 ). There was large variation in the percentage of rotten nuts with most in Tanzawa (100\%), 1017 (93\%) and Eastern Sunrise (60\%). Less than $10 \%$ rotten nuts were found in the cultivars Disk 1, Disk 4 and Pukekura. $P$. castanea was isolated from all 21 cultivars and incidence ranged from $25-85 \%$.

TABLE 2: Variation in nut-rot within the chestnut cultivar collection at Waikato Research Orchard (Hamilton) and Lincoln University Orchard (Canterbury).

\begin{tabular}{cccccc}
\hline Cultivar & Rotted- & Predominant & \multicolumn{3}{c}{$\%$ P. castanea isolation } \\
& nuts & fungus & Stylar & Hilum & Total \\
& $(\%)$ & isolated & end & end & nuts \\
\hline
\end{tabular}

\section{Waikato Research Orchard}

\begin{tabular}{|c|c|c|c|c|c|}
\hline Tanzawa & 100 & 2 & 25 & 25 & 25 \\
\hline 1017 & 93 & 1 & 53 & 53 & 60 \\
\hline Eastern Sunrise & 60 & 1 & 46 & 46 & 73 \\
\hline 651 & 46 & 1 & 66 & 73 & 80 \\
\hline 605 & 46 & 1 & 40 & 60 & 67 \\
\hline 1002 & 40 & 1 & 60 & 50 & 70 \\
\hline 1005 & 40 & 1 & 40 & 30 & 60 \\
\hline 1008 & 40 & 1 & 40 & 40 & 53 \\
\hline 1010 & 40 & 1 & 33 & 40 & 60 \\
\hline 1013 & 40 & 1 & 66 & 60 & 86 \\
\hline 1714 & 33 & 1 & 33 & 26 & 40 \\
\hline 1004 & 23 & 1 & 38 & 31 & 60 \\
\hline Horton & 23 & 1 & 38 & 54 & 70 \\
\hline 1011 & 20 & 1 & 26 & 33 & 46 \\
\hline 1713 & 20 & 1 & 13 & 53 & 66 \\
\hline 907 & 16 & 1 & 8 & 25 & 25 \\
\hline 1015 & 10 & 1 & 20 & 30 & 50 \\
\hline Pukekura & 9 & 1 & 0 & 36 & 36 \\
\hline Disk1 & 8 & 2 & 8 & 33 & 33 \\
\hline Disk4 & 8 & 2 & 0 & 25 & 25 \\
\hline 1007 & 0 & - & 26 & 0 & 26 \\
\hline \multicolumn{6}{|c|}{ Lincoln University Orchard } \\
\hline Long Bay 4 & 26 & 2 & 13 & 0 & 13 \\
\hline Herb Farm & 26 & 1 & 13 & 20 & 20 \\
\hline 1015 & 16 & 1 & 42 & 8 & 50 \\
\hline 1005 & 10 & 1 & 40 & 20 & 50 \\
\hline Crewenna 1 & 0 & - & 20 & 40 & 40 \\
\hline Don Whelan & 0 & - & 20 & 13 & 26 \\
\hline
\end{tabular}

${ }^{1} 1$ = Phomopsis castanea, $2=$ Penicillium $\mathrm{sp}$. 
P. castanea was associated with all the six cultivars from the Lincoln University Orchard and contributed to 25\% rotting in nuts of cultivars Herb Farm and Long Bay 4. Some rotting was observed in 1015 and 1005, while Crewenna 1 and Don Whelan cultivars were free of disease. Other fungi isolated from rotted nuts were species belonging to Penicillium, Fusarium, Pestalotia and Botrytis.

No trends were obvious in relation to $P$. castanea infection of either stylar/hilum ends and no correlation was observed between number of pellicle intrusions and rotting severity. The frequency of $P$. castanea isolation was not related to the presence, absence or extent of rotting. Morphological and culture characteristics of $P$. castanea isolates from diseased or healthy nuts and from nuts showing distinctly different symptoms were identical.

\section{DISCUSSION}

$P$. castanea was the most common fungus encountered and by far the most prevalent rot fungus in the North Island grown nuts. However, while storage rots of chestnuts have been reported from around the world, only in the southern hemisphere countries of Australia (Washington et al. 1997), Chile (Montealegre and Gonzalez 1986) and New Zealand (Klinac 1998; McNeil 1996) has $P$. castanea previously been reported as a serious problem.

The reasons for this may be partly climatic. Most of the New Zealand locations (Fig. 1) showing the highest incidence of rot were found in the warmer, high rainfall, high humidity areas of the northern North Island and least in the drier areas of the South Island. This would agree with the observation (Ogilvy 1999) that most Phomopsis infection seems to occur when it rains during flowering (December-January). Other pre-disposing factors cannot be excluded (eg. tree age, mix of cultivars and pollenisers, orchard management etc.) but were not part of this survey.

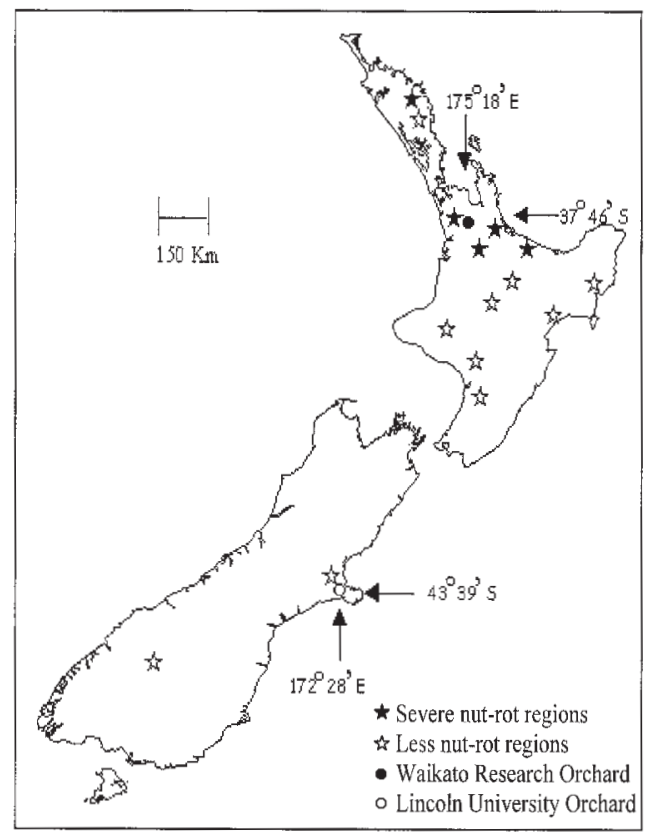

FIGURE 1: Map of New Zealand showing chestnut sampling locations. 
An interesting observation was that, in multi-embryonic nuts, one embryo might be totally rotten even though the other remained healthy, even after prolonged storage. The pellicle, in such cases, could act as an effective barrier. This may possibly indicate separate infection events or since chestnuts also exhibit xenia, pollination-related genetic differences in the embryos leading to resistance.

Many chestnuts also showed $P$. castanea infection, but still remained free of rot. Why this occurs remains unclear. Further study will be needed to pinpoint the factors responsible for infection of kernels by different fungi and subsequent rot development. With this information, it may then be possible to develop control measures for the disease.

\section{REFERENCES}

Klinac, D., 1998. Phomopsis in New Zealand chestnuts. Aust. Nutgrower 12(3): 31-34. Klinac, D. and Forbes, C., 1998. Chestnut post-harvest storage and handling. Aust. Nutgrower 12 (1): 18-20.

McNeil, D.L., 1996. The nut industry in New Zealand - An overview. Aust. Nutgrower Proc. 1996 Conf:: 4-11.

Ogilvy, D., 1999. Phomopsis-when does it strike. Aust. Nutgrower 12(4): 16-18.

Montealegre, J. and Gonzalez, S., 1986. Hongos causantes de pudricones en frutos de Castanea sativa Mill. Simiente 56: 166-169.

Washington, W.S., Allen, A.D. and Dooley, L.B., 1997. Preliminary studies on Phomopsis castanea and other organisms associated with healthy and rotted chestnut fruit in storage. Australasian Pl. Path. 26: 37-43. 